DOI: https://doi.org/10.24113/ijellh.v8i1.10404

\title{
Redefining Motherhood: Problems of Surrogacy in Kishwar Desai’s Origins of Love
}

James Joseph

Research Scholar, Asst. Professor

St. Mary's College

Sulthan Bathery, Kerala, India

jamesjcheriv@gmail.com

\section{Dr. Sr. Celine E}

Research Guide

St. Teresa's College

Ernakulam, Kerala, India

There is a great deal concerning the body of woman. The flesh trade is now a legalized business. Organ transplantation fetches lot of money to the middleman. Kishwar Desai presents the story of multi-million business of surrogacy and artificial pregnancy going on in the modern world in her novel Origins of Love. Surrogacy is the recent trend found among the economically backward women in India. Fertility clinics are mushrooming in India. The desire of the couples for a child is exploited to its maximum by the doctors. The need for money to solve some crucial problems in life drives some young women to lend their womb for upbringing the child of some other couple. The money minded doctors and the agents, who supply the surrogate mother and the commissioning parents, make the money-deal to their maximum advantage. There are many issues related to the so called womb trade. Is it 
DOI: https://doi.org/10.24113/ijellh.v8i1.10404

not violence against motherhood and womb? Is it not a denial of a child's maternal care?

Who will be the mother to the child? How will a woman simply forget the fruit of her womb?

The psychological emptiness the mother feels is so severe that it may create mental

imbalance. When the healthy embryo is selected what will be the fate of the rejected

embryos? Is it not an abortion outside the womb? This paper presents the problems related to surrogacy in the light of the novel Origins of Love.

Keywords: Surrogacy, Fertility Clinic, IVF, Embryo, Donor

In his essay on "Governmentality", Foucault (1991) defines discipline as referring to the management of states as well as the management of all populations. Lori Reed \& Paula Saukko clearly explain the intention of Foucault in writing the essay.

Governmentality bridges the micropolitics of disciplining the body and mind and the macropolitics of governing the nation-state via management of populations by various programs and institutions, such as education and health care. Doing so draws attention to parallels between historical modes of political governance and the way in which we govern our bodies and selves in our everyday intimate lives. The aim of Foucault's works on clinics, asylums, prisons, and sexuality was to delineate a particular mode of governing people's bodies and minds or souls typical of the modern period. (Reed 5) As part of disciplining, female body undergoes different types of transformation. Motherhood is considered natural for women. So women are supposed to undergo any kind of treatment to become a mother. In “ 'Doing What Comes Naturally . .' Negotiating Normality in Accounts of IVF Failure" Karen Throsby says that the modern treatment for pregnancy is so natural that any woman who refuses to undergo such treatment is considered selfish and arrogant. 
DOI: https://doi.org/10.24113/ijellh.v8i1.10404

Therefore, the nonmother who "refuses" treatment is rendered as lacking the self-sacrificial qualities of normative ("natural") womanhood/motherhood (Throsby 239). The treatment of IVF produces new forms of governance of the female body. The responsibility and the pain of conceiving a child becomes a prime concern of the couples. However, "this drive toward treatment reflects a more pervasive assumption that women, in particular, should "do everything possible" to have a child. ... These practices are profoundly gendered, with the responsibility falling primarily to the female partners" (248). The treatment of IVF is not just all about reproductive process but rather it creates a new discourse on female body. ... for all its "newness," IVF is both produced by, and productive of, perniciously familiar discourses about the female body as "naturally" reproductive, and unpredictable and liable to failure. This construction results not only in the female body being rendered as an object of medical surveillance and intervention in ways that are easily made invisible through the naturalization of those interventions, but it also means that the female body can be held responsible for the failure of those interventions. This burden of responsibility becomes lost in the construction of "the couple" as the IVF patient - a construction that is sustained by assumptions of reproductive labor as a "natural" part of femininity. (Throsby 248-249)

In India there are many clinics to foster surrogate mothers. Though the government doesn't promote such practices there is no law against such practice. 'Madonna and Child Clinic' at Gurgaon owned by Dr. Subhash Pandey already accommodates six ladies of whom two are already pregnant through IVF (Invitro Fertilization). The normal charge for nurturing a pregnancy was twenty lakh rupees. But when there were two gay couples from Germany and Britain in need of a child, the charge rose up to forty lakh rupees because dealing with homosexual cases in India was still complicated; it was largely a taboo subject and the laws 
DOI: https://doi.org/10.24113/ijellh.v8i1.10404

did not help either. And countries like Germany, Spain, Israel, France and Belgium had already issued notifications that IVF clinics in India should not entertain surrogacy for citizens of their country (Desai 21). It shows that people in the Western culture still value life and human dignity. But the biggest democratic country - India - could afford to have all such practices without any trouble from the government. These practices now go on as something approved by the government or as a part of the state apparatus - mother and child welfare.

Kishwar Desai wants the reader understand how even the protectors or promoters of life go against the principles they professed. Dr. Subhash Pandey was supported by her doctor wife Anita and colleague Ashok Ganguly. When Dr. Pandey felt some uneasiness about homosexuals being given children to look after, his wife reminded him that he was a doctor and not a priest (22). No morality works beyond the power of money. Even the threats from Swami Ganga and the Pratha Suraksha Sansthan, an organization which claimed to be working towards preserving the moral traditions of India and opposed children being given to couples, did not upset Dr. Anita. Her answer to her husband was Indians had to modernize. Can anything be considered modern that functions against tradition? Will Indians be modernized if we adopt all the western customs? Or is the adoption of western culture the criteria for modernization? Kishwar Desai highlights the role of the powerful in implementing in the society certain customs which inflict pain and suffering. On the pretest of modernization, the influential sections in the society make use of the economically weak sections. The economical need of women is exploited by these doctors and their team, thwarting away the existing social norms and traditions. The gang that works behind the womb trade is so powerful. Mr. Sharma is the supplier of surrogate women. We get an idea about Mr. Sharma from these lines: 
DOI: https://doi.org/10.24113/ijellh.v8i1.10404

Sharma was the archetypal supplier. He was the guy you called when you needed foreign liquor at short notice, a driving licence without passing the test, a file pushed in a government office, or a new building given clearance without the proper fire-and -safety regulations being adhered to. He could get you medical supplies, oxygen cylinders, expensive perfume, imported cameras ... No one knew his first name or where he came from, but he had made a small fortune from his ability to supply whatever the client wanted. His connections were many, and everyone supported him. He was invaluable in a city like Delhi. (25)

This description about Sharma gives us the idea how unlawfully things happen in the society and how the government departments support such illegal practices. Violation of law is violence against those who obey the law. In this sense surrogacy is a systemic violence embedded in the medical field.

Those women who are ready for carrying the embryo are selected after a long process. They are thoroughly checked by the doctors and they are provided nutrient food and skin care. Most clients from Europe preferred fair women and so dark skins were always a problem for the agents in India. But Dr. Subhash would find a solution: "With more expensive clothes, a protein-rich diet, bleach to lighten her skin, and may be some makeup, Sonia could do. Better photographs would have to be taken (especially for the website, which was designed to appeal to Western tastes), in soft pastels and with floral borders" (26-27). Nazir Ali, a Customs Officer would see a new form of colonization in the whole business of surrogacy:

Those goras are having fewer babies than us, you see. They are getting older, while we have a young population. So now they want to reverse that, get it? 
DOI: https://doi.org/10.24113/ijellh.v8i1.10404

.... They want our women to stop having babies for us and have them for those goras instead. Our women do the work, and their population goes up. Don't you see it's a plot? A new way to colonize us. (40)

Once, a container containing embryos from UK was seized by Ali and his subordinate Mehta. They made use of this chance to make money. The container contained twelve cans of embryos and they priced fifty thousand each for releasing the consignment. At the same time they called the press and informed them that they have confiscated the lot (41). In the whole business there is no morality working out. The Customs get the double advantage of getting their name and photo published in the newspaper and a huge amount as bribe. The ultimate suffers are the poor women who agree to nurture these embryos in their wombs taking all the physical pains till the birth of the child and the mental pain after the separation of the child.

Simran, the social activist goes to London in search of the donor of the sperm, who is said to be Edward Walters, a person with the mission of spreading the seed (45). So far he has fathered fifty children and still ready for the generous deed of donating his sperm to the needy women. His only condition is that once a child is born, the child should not see the father or rather the mother should not tell the child about his/her father. Simran arrived in London to find out the reason for the infection of HIV in the new born child Amelia, who was born to a surrogate mother. The mother did not have HIV; the embryo might have been infected with the virus. Simran approached Edward on the pretest of getting a child with his help.

Throughout the novel the craving of the couples to get a child by any means is discussed. Ben and Kate are trying their level best to get a child after three miscarriages. To have a child is a genuine need of a married couple. But in the modern society "two total strangers would meet over a glass of wine (and cold milk) to plan their future child, who would start his or her journey to life in a plastic bowl" (52). This situation can very much 
DOI: https://doi.org/10.24113/ijellh.v8i1.10404

affect the stability of the society. The parents may not feel any kind of attachment or commitment to the child. The emotional bond between parents and children will be less and children can be abused or mistreated by the same parents. Thus Kishwar Desai unfolds the latent element of violence by explaining the nuances of surrogacy through this novel.

The facilities provided in the clinic run by Dr. Subhash were comparatively good enough to compete with other such clinics blooming in the different parts of the country. $\mathrm{He}$ did it as a marketing strategy and to provide privacy for the gestational mother. This privacy was also essential for the donor or commissioning parents to spend time with their expected child. The facilities varied according to the amount charged from the commissioning parents. Here the concern was not the pregnant woman or the child, but the status of the institution and the satisfaction of the customer, who usually was a foreigner. The real intention of making anything good is not to provide comfort for the deserving women in the clinic. No mercy is shown to these women once they are out of the clinic after the delivery and all the dealings are completed. The total process of surrogacy is done as a business deal. No humanitarian concern is given to the willing women. The womb is just considered as a storage place of the embryo or as a fertile field where crops are cultivated. As long as there are crops, the land is protected and provided with water and necessary manure.

The English and Skill Development lessons given to the women in the clinic is another strategy used by Dr. Subhash and team. Since the commissioning parents want educated women to foster their child, the clinical team wants to create an impression that all the women in their clinic are well educated and are able to write and read English. Simran Singh, Anita's cousin and social worker, gives them English lessons. They are given basic skills in communication. Many of the women kept in the clinic didn't have even the primary education. So Simran had to teach them the alphabet of English. Preeti, a pregnant woman, learnt to write her name in English, eventhough "the letters were all uneven, very much like a 
DOI: https://doi.org/10.24113/ijellh.v8i1.10404

child's" (70). These women are molded to the taste of the Western couples. This learning of English will no way help them when they reach their homeland, because they never get a chance to use any of the words they learnt; they don't get enough food to feed their hungry stomach; they have to continue in their previous situation once they reach home. So the new learning gives no advantage to these poor women; the foreign parents are also to some way cheated because they are made to believe that the woman who carries their child is educated according to their customs. But in fact no literacy is provided other than a few lessons given during the pregnancy. Thus there is no ethics at play in the whole dealing of surrogacy. This again proves that surrogacy is another discourse of systemic violence existing in the society.

In order to make the clients believe that the women are educated Class ten certificates are produced. Mr. Sharma obtained the stamped certificates from the school and space for writing the name is kept blank. When Subhash mentioned that those certificates are incomplete, Ganguly said with a smile: "You don't get it, do you? We are the ones who fill the names in" (72). Subhash felt "sorry for the women who would accept the false certificates as just another means for them to earn large sums of money legitimately. They would not even question the web of lies which surround their new identities. It was how the country functioned" (73). With a person like Mr. Sharma everything was possible. And Mr. Sharma is only one among the thousands in the country working for such needs.

Kishwar Desai uses Simran Singh to permeate into the clandestine business of rich classes, including doctors, Customs officers, business agents etc. Simran's role as a social worker is adept to intrude upon the secret areas of an illegal practice going on in the society unperturbed or unchallenged. Simran is presented as an unmarried woman who "preferred to spend her time either working in juvenile-detention centres, or sorting out problems for them at their hospital" (71). She has adopted Durga, a teenager accused of killing all the thirteen members of her family present at her home at the time of committing the crime. 
DOI: https://doi.org/10.24113/ijellh.v8i1.10404

The issue of surrogacy has many problems, both physical and emotional. Many of the mothers get attached to the child after giving birth and when they hear that they will never see the child again creates havoc and huge wrench in them. Dr. Anita has pointed out the awesome reaction of some women: “...it was all the more difficult when a beautiful white baby emerged from between their dusky thighs, as though they had given birth to a god or goddess. It was a miracle they would remember for the rest of their lives - and their excitement was palpable" (74). In another case the breast milk was carefully packaged and sent to Australia where the child would feed from it for at least three months. The mother of the child felt connected to her child through this process. As Subhash was experiencing all these changes happening in front of his eyes, he began to think how globalization changed the concept of motherhood; it has made "motherhood complex almost beyond belief and its boundaries were constantly shifting, as everyone searched for the immaculate conception and birth" (74).

The number of surrogate mother increases in India year after year. In US or in Europe women won't take up such task because they very well know what they are venturing into. Even "in India, no self-respecting, educated woman from a middle class background would agree to have another couple's baby - not unless there was a very compelling reason" (75). The advances in the medical field and the introduction of IVF have transformed the lives of women and their destinies, and disrupted the concept of family and family relationships in general. In order to show this complexity Kishwar Desai adds another incident happened in the clinic.

In his hospital last year a mother had given birth to her own daughter's child, since the daughter was unable to carry an infant to full term. .... Subhash, along with many millions of Indians, had pondered over the fate of the father of the child in this case. He had tried to imagine the bizarre 
DOI: https://doi.org/10.24113/ijellh.v8i1.10404

situation on which the man was caught. Not only was his mother-in-law injected with his sperm, she was the mother of her own grandchild. Did that make him both the grandfather and the father? (75)

How cunning a man can be in dealing with sperms and eggs is shown to us through the character of Dr. Ashok Ganguly. He was thinking about how to blackmail the donors of eggs and sperms to prevent possibility of misuse. If the remaining sperm or egg is used without permission another child can be born with the same DNA of a legitimate child or the parents. So in future, if a child claims for his/her parenthood in these donors, their life will be in trouble. The legitimate child may have to shockingly hear about his/her brother/sister living somewhere and claiming all the rights as he/she would. Thinking about this possibility, Ganguly was preparing to charge an amount from the donors to destroy the remaining sperms and eggs, and to keep the deal completely secret and out of danger (76).

Kishwar Desai presents the story of Radhika, a 16 year old girl who was pregnant with twins for a gay couple from France, to show that the majority of the women involved in the womb business are helpless women. She got involved into the business because her husband, a construction worker suffered head injury from the site. In order to meet the expensive treatment she needed money. Sharma met her on the roadside in such situation and she was trapped into an endless cycle of surrogacy (78). Radhika, already a victim of child marriage was enslaved into another social evil of surrogacy. The reason for choosing adolescent girls is that they have better eggs and the chance of miscarriage is less. The exploiters know how and when to approach the helpless people under the guise of a saviour.

There came another girl of fifteen years into the clinic led by Sharma. She came there to donate eggs for and infertile Indian woman who was in her forties. The woman did not want her husband to know she was unable to have children. The eggs would be stored under her name. The girl was fair with curly hair just as the client had demanded (77). 
DOI: https://doi.org/10.24113/ijellh.v8i1.10404

The case of Sonia reveals to us another area of women being exploited. Sonia, a

widow, now living with her cousin is offered to the needy men in Delhi. She was not allowed to go out without the permission of her cousin Rohit, a peon at the home of the Delhi Health Minister, Renu Mishra. One day Rohit hit her on the face for going out to meet the doctor without his permission. After washing the bleeding nose Sonia thought "she had something else to sell, putting her arms around her abdomen and pressing it as the doctor had done" (83). The visitors for Sonia were mainly the assistants working in Health Minister Renu's office. This is another indication how the Health Department functioned in our country. No one cared what the officers did and what type of people is employed in the office. Rohit tried to please all the officers by all means possible (offering Sonia also) because he knew one day he too would be able to sit on a chair next to the Chief Minister (86). It was difficult for a widow to live alone without the support of a man in our society. So Sonia had no other option than obeying Rohit. Sonia took every precaution not to get pregnant or to infect with any disease as it would affect her chance for earning money through surrogacy. She needed money to educate her two children now living with her parents in the village. She had to sell her body to keep her care taker happy and she had to rent her womb to keep her children and parents happy. When Sonia told Rohit about the plan of surrogacy, his shrewd mind thought of another plan. Renu Mishra wished to have a child to continue the dynastic rule. According to the present condition in Indian democracy, ruling was a family affair. Renu Madam could rule for twenty years, but what after that? (198). So Sonia was used as a surrogate for Renu and Vineet Bhai, her close associate. The question to be asked is whether an economically backward woman is an object to be exploited. Trespassing into the rights of a woman is not yet considered violence because it is part of the approved system - a system supporting male dominance. Anything that has become part of the system is unchallenged before the law. 
DOI: https://doi.org/10.24113/ijellh.v8i1.10404

Even when the doctors at the clinic claim that they take all the precaution in the IVF the reality is very different. In the case of Sonia, she was offered to many men as a sex worker and the same Sonia is used as surrogate for many couples. How can we assure that she is not infected with any disease?

The problem related to Amelia was so complicated that neither the doctors nor Simran could find a solution. Amelia, born to British couples Mike and Susan Oldham from Preeti, tested HIV positive. No one knew from where the child got the disease because the blood samples of the couples did not have any trace of HIV. The test result of Preeti before the IVF was also clear. Now to test the blood once again, Preeti was not available because immediately after receiving the amount she left the clinic and no whereabouts was known. Amelia, the premature baby was kept in the incubator while the parents arrived to receive the child. In order to pacify the parents of the child, they are offered a tour package to Rajastan. The most tragic part of it was that the couples died in a freak car accident while returning from Jaipur. It seemed that the car had got fire following the crash and only the Oldham's charred bodies were recovered (115). But the driver had a miraculous escape. In this condition there arose the question of the citizenship of the child. "Where would the child go, and to whom did the child belong, with both the parents dead and the surrogate missing?" (116). Here the child has become a scapegoat of this unnatural progenitive process.

Simran Singh wanted to find out the cause of the HIV in baby Amelia. She went to London and met Edward Walters as his name was scribbled on the corner of the application form filled by Mike and Susan. After a prolonged and troublesome investigation Simran came to know that the sperm was collected from Martin, now a twenty year old boy, who was born to Susan through Edward. Martin and Peter were gay couples and they wanted to have a child. When Susan came to know that Martin was HIV positive and would die soon, she wanted to keep his memory through him. She took him to Mybaby.com clinic run by Dr. 
DOI: https://doi.org/10.24113/ijellh.v8i1.10404

Hansen and deposited his sperm with the surety that the HIV will be separated from the sample before being used for the union. The egg was from Susan. Without removing the virus the embryo was sent to India just after one week and thus the child was born with HIV. Now another problem is revealed. Amelia is a result of incest -Susan's egg and Martin's sperm: mother- son relation. And Edward is the grandfather of Amelia as Martin was his son from Susan. Thus the web of complications surrogacy, IVF and ART create is innumerable. It was not only those who could not conceive or bear a child opted for a surrogate child but those who want to preserve their figure or career, or both. The beauty conscious ladies with affluent richness can easily avoid the pains of pregnancy and they can go on with their profession uninterrupted. As long as there are poverty stricken women, these rich ladies can afford to have a child as a commodity brought from the market.

Surrogacy becomes a violation of women's rights on other grounds as well. As Kishwar Desai puts it through Simran, "they are being completely and thoughtlessly exploited - especially when they were given cycles of hormones to produce donor eggs, and persuaded to carry multiple embryos" (111). Sometimes the drugs given to induce egg production could be life threatening. These drugs caused physical discomfort and mental stress (209). Kate, a lady who wanted to have a child through IVF, had such a bad experience in the clinic. The surrogates are forced to undergo caesareans to adjust to the busy schedule of the commissioning parents.

Many of the problems related to surrogacy would have been avoided if the couples opted for adoption. Though the process of adoption is complicated, a parentless child would have been saved with adoption. But all the desiring parents wanted a child with their DNA, their genes, and everything their own. No one wants to settle for a child who might have nothing to do with him/her (134). 
DOI: https://doi.org/10.24113/ijellh.v8i1.10404

The women chosen for surrogacy are so young that they can be used again for other couples. Many of them are young ladies either abandoned by their husbands or widows or adolescent girls who are trapped by the agents. As long as they don't have a better option to go anywhere or to live a better life somewhere they are used again by the doctors. So like bonded slaves, they work on the demand of other people and produce children for some strangers. These women have to leave their home, if they have one, and live like a cloistered nun in a clinic. When someone in their village asks about them the answer given to them would be that they had gone to the city for work. No one would know that their neighbouring lady had gone to carry the blastocyte/embryo of someone far off this country.

There is a group of people to totally exploit the couples who are craving for a child and the women who are in dare need of money. When these people are making a deal, there is not enough time left to think about the consequences of the deal. The agents and the doctors can squeeze the couples to extract more money and bargain with the surrogate women for a lesser amount. So the margin left for the middlemen and the doctors is so huge that they can start another clinic in some other part of the country.

The possibility of mix up of the sperms with the eggs of another woman is so common an issue. The commissioning parents may not get the child from the union of their sperm and egg. Though the doctors claim the confidentiality and complete safety for the embryos, none of the parents go for a DNA check up after they receive the child. The seized container of embryos which was addressed to the Madona and Child clinic at Gurgaon was given to Freedom Hospital at Mumbai. All the cans containing the embryos had address of the couples for whom the embryos were created. This exchange was done by Customs Officer Nazir Ali because of the deal he had made with Dr. Wadhwani. Ali had told Diwan Nath Mehta, a subordinate officer of Ali, to deliver the consignment at the Freedom hospital at Mumbai. Mehta was offered a bundle of thousand rupee notes for this job. Even though Dr. 
DOI: https://doi.org/10.24113/ijellh.v8i1.10404

Pandey was ready to offer a bribe to get the consignment released, Ali told that the container was then the property of the government and they could not do anything. He consoled the Pandeys that the next container would be given to them as a compensation for the present one.

The embryos sent to the Freedom Hospital in Mumbai were used for the experiment in stem cell surgery. Many patients with fatal injuries and prolonged diseases were experimented with embryonic stem-cell surgery, which was still banned in India. The Customs Officer Nizar Ali, who was fighting against the new method of colonization, knew that the embryos sent to Dr. Wadhwani were not used for producing white goras. So while sending the containers to Freedom Hospital he could get both money and his jihad fulfilled. The commissioning parents at the Mybaby .com clinic in the UK used to give more samples to the clinic in order to select the healthy embryo for the surrogacy. After the selection the remaining embryos were sent to India as per the demand from India.

Dr. Ashok Ganguly who is so pragmatic in making money did not agree with Dr. Pandey in refusing the demand of the gay couples opting for a child. He could demand more money from the couples if they are gay because in many countries they were not allowed to have a child. As there were complications in their countries, these couples came to India for fulfilling their wish. Dr. Ganguly made use of this chance to exploit them. Knowing that Dr. Pandey was not favouring this practice Dr. Ganguly started his own clinic at Delhi named New Life. He had great linkage with Dr. Wadhwani of Freedom Hospital. Dr. Ganguli made use of the embryos for both surrogacy and embryonic stem-cell surgery. He wanted to be well established before the laws regarding stem-cell surgery were approved by the government. Having found that Amelia was HIV positive, Dr. Ganguly took Preeti, the surrogate mother away from Madona and Child Clinic. On the way she was thrown out of the car and suffered serious head injuries causing coma. She is now being treated at the New Life clinic with 
DOI: https://doi.org/10.24113/ijellh.v8i1.10404

embryonic stem-cell surgery. Dr. Ganguly was funded by Viva-Bio, a company that supplies medicines related to stem-cell surgery. He was used by the company to conduct experiment with the medicine on the unconscious patients. He could go to any level as far as money is concerned.

The multibillion dollar business of surrogacy causes innumerable problems to women and children in the society. The dignity of a pregnant woman is bargained; the relations are redefined; the life of a new born child is at stake; ethical principles in medical field are diluted; corruption among the professionals and bureaucrats increases; the social system of family is disturbed. When an illegal practice is supported by the state, the concept of motherhood is redefined. 
DOI: https://doi.org/10.24113/ijellh.v8i1.10404

\section{Works Cited}

Desai, Kishwar. Origins of Love. London: Simon \& Schuster, 2012.

Reed, Lori \& Paula Saukko, eds. Governing the Female Body: Gender, Health, and Networks of Power. New York: State U of New York P, 2010.

Throsby, Karen. “ 'Doing What Comes Naturally ..' Negotiating Normality in Accounts of IVF Failure". Governing the Female Body: Gender, Health, and Networks of Power. Eds. Reed, Lori \& Paula Saukko. New York: State U of New York P, 2010. 233-252. 